\title{
원조효과작업반 클러스터 C (원조투명성 및 예측성 IT) 전체회의
}

\section{I. 회의개요}

표제 회의가 2011년 7월 6일 파리 OECD 본부에서 원조효과작업반 클러스터 C의 주최로 김형규 주재관이 참석한 가운데 개최 됨.

\section{II. 주요내용}

- PD 최종평가(원조예측성) 결과 분석. 사무국은 금번 발표된 파리선언 최종평가결과에서 원조예 측성과 관련된 지표들은 진전이 없거나 오히려 이전보다 악화된 것으로 나타났음을 밝히고 이러 한 부정적 결과의 원인 중 하나로 원조예측성 산정방식의 비현실성을 제시 함.

- 원조 예측성 제고를 위한 노력의 일환으로 민간 컨설턴트(Mokoro Ltd)를 통해 다양한 모범사례 들을 분석하여 일반적인 교훈 및 권고사항을 도출 함.

- 공여국들이 반영해야할 권고사항으로 다년간 프로그램(Multi-annual programming)의 확대 운 영, 국별 지원에 있어서 일관성과 유연성의 조화 등이 있고, 수원국들의 고려사항으로는 신뢰성 있는 공공재정관리시스템 $(\mathrm{PMF})$ 구축 및 투명한 재정관리, 효율적인 원조관리정책 수립 및 시스 템 구축 등을 소개하였음. 공여국-수원국 공통사항으로는 원조자금의 투명성 확보를 위해 원조 정보 공유, 다년간 운용계획 공동수립 등이 있음.

- CABRI(Collaborative Africa Budget Reform Initiative)가 원조재원의 투명성에 대한 아프리카 의 입장을 밝힘. 수원국내에서의 재정투명성, 원조투명성, 개발효과는 상호 밀접한 연관성을 가 지며 이를 위해서는 기술적 기반과 관련 인프라가 확보 되어야 하며 민주적 - 경제적거버넌스의 핵심인 공공재정 관리의 중요성을 강조 함.

- DAC 통계작업반은 원조투명성 제고를 위한 장기적 - 지속적 노력의 일환으로 DAC의 원조액보고 시스템 $(\mathrm{CRS})$ 의 활용확대를 제안. 원조투명성은 정치적 - 선언적 공약과 더불어 계량적 - 통계적 조치가 수반될 때 실질적인 진전이 기대 됨.

- 사무국은 Cluster C의 입장문서 초안(Consensus on Transparency and Aid Predictability Increasing Transparency and Improving Aid Predictability for better Ownership and Accountability)을 회람하고 각 회원국들의 의견을 7월 9일 이전까지 알려줄 것 요청 함. 